\title{
Üniversite Gençliğinin Değerleri: 20 Yil Sonra Ne Değişti?
}

\author{
DOI: 10.26466/opus.571209 \\ Abdullah Topçuoğlu* - Gamze Aksan** \\ * Prof. Dr. Selçuk Üniversitesi, Edebiyat Fakültesi, Sosyoloji Bölümü/ Konya/ Türkiye \\ E-Posta: atopcuoglu@gmail.com ORCID: 0000-0003-0983-1014 \\ ** Dr. Öğretim Üyesi Selçuk Üniversitesi, Edebiyat Fakültesi, Sosyoloji Bölümü/ Konya/ Türkiye \\ E-Posta: gaksan@selcuk.edu.tr \\ ORCID: $\underline{0000-0001-5051-4630}$

\section{Öz}

Bu çalışma temel olarak üniversite gençliğinin değerlerini konu etmektedir. Özellikle 2000'li yıllar sonrasında toplumun her alanında yaşanan gelişmelerle birlikte toplumsal değiş̧imin hızı artarken gençliğin bu durumdan etkilenen başlıca kategorilerden birisi olduğu açıktır. Öyle ki, "gençliğin nereye gitmekte olduğu" hem gündelik ilişkilerde hem de toplumsal düzeyde, toplumun başat kurumlarının;siyasetin, eğitimin, dinin ve ailenin özellikle dert edindiği önemli bir tartışma alanıdır.Bu noktada yorum ya da eleştiriye temel izlenimleri ve çıkarımları destekleyecek bilimsel çalışmalara ihtiyaç duyulmaktadır. Bu çalışmanın esin kaynă̆ ise1999 yılında gerçekleştirilen "Üniversite Gençliğinin Değerleri" (Topçuoğlu, 1999) isimli araştırmadır. Geçen 20 yılın ardından, bugün üniversite gençliğinin değer konusundaki tutum düzeyleri ve bunun farklı değişkenlerle ilişkisini anlamaya çalışan bu çalışmada kıyasa tabi tutulan ana unsurlar, değişim konusunda çıkarım yapılabilmesi adına, ismi geçen çalışmada kullanılan ölçme araçları çerçevesinde ele alınmıştır. Çalışmada devlet ve vakıf üniversitesinde öğrenim gören 927 katılımcıdan elde edilen veriler doğrultusunda bazı sonuçlara ulaşılmıştır.Analizler sonucu ayrımlaşan faktör grupları ve diğer değişkenler değerlendirilerek, esin çalışmasındaki bulgularla kıyaslanmıştır. 20 yıldaki değisşimi görebilmeye yardımo en çarpıcı bulgulardan birisi ise her iki araştırmada da kullanılan Schwartz'ın(1992) değer yönelimleri ölçeği üzerinden bu çalışmada ayrışan faktör gruplarından bireycive maddeci değerler ile manevi değerler arasındaki olumlu yöndeki korelasyon ilişkisidir. Bu durumda gençlik bir taraftan dünyevi sayılabilecek değerleri, imajı ve hırslı olmayı önemserken diğer taraftan manevi ve dini değer eğilimlidir. Oysa 20 yıl önce bu durum tam tersi olarak, olumsuz yönlü korelasyon ilişkisi ile anlamlllık kazanmıştı. Diğer bulgular ile birlikte üniversite gençliğinin değerleri anlamlandırılmaya çalışılırken bu çalışma, tekrar çalışmaların özellikle sosyolojik değişim ve dönüşümü görebilmeye yardımcı önemli yönlerinin olduğunu hatırlatmaktadır.

Anahtar Kelimeler: Toplumsal değerler, Üniversite gençliğinin değerleri, Değişen gençliğin sosyolojisi. 


\title{
The Values of University Youth: What Has Changed After Years?
}

\begin{abstract}
This study is basically about the values of university youth. Along with the rapid sociological changes, it is obvious that the youth is one of the fore-coming social layers which has been affected by the developments being lived with in all components of the society especially following the years of the 2000's. Therefore, the question "What direction do the affairs of the youth evolve?" is a big concern both among the individual sand the society groups; especially this question is an important issue that keep busy some leading social actors of the society such as politicians, educational institutions, religious organization sand the family members. At this point, there is an obvious need for critical thinking and scientific studies which will support basic perceptions and observations. This research study is inspired by the study named "The Values of University Youth" which was implemented by Topçuoğlu in 1999. After 20 years, in this study, which aims to understand today's university youth's attitude level towards values in relation with different variables, the assessment instruments were taken from the cited research study so as to ensure reliable comparison and reach correct conclusion. The data, which is derivedfrom 927 participants who are studying at public corprivate universities, is used to make deduction. The 7 factor groups that have been reached at the end of the analysis and the other variables were evaluated and compared to the findings that was gathered in former study. One of the most striking findings which helped to see the change safter 20 years is that byusing Schwart's Human Value Questionnaire(1992) the positive correlative relation between distinctive individüalist group sandspiritual groups is identified. In an other word, theyouthgiveimportancetothematerialvalueslikeimageorbeingambitious on one side while they have a religious tendency on the other side. However, this was just opposite 20 years ago with a negative and opposite correlative relation. Along with other findings, this research study reminds that replicated studies can be particularly effective in highlight in gthesociological changes and transformation while it was trying to understand the values of university youth.
\end{abstract}

Keywords: SocialValues, The Values of UniversityYouth, The Sociology of Changing Youth 


\section{Giriş}

Değerler toplumsal ilişkileri belirleyen ve onları yeniden inşa ederek sosyokültürel dünyamızı anlamlandırmaya yarayan önemli sosyolojik olgulardan birisidir. Genel olarak sosyal bilimlerin, özelde ise sosyolojinin pozitivizmin etkisiyle değerler konusu ile ilgili tartışmalara yaklaş$\mathrm{ml}$; kavramın anlam, alg1 ve tutum gibi objektif olarak açıklanamayacağ düşünülen yönlerine atfen, nesnel bilimsel süreçlere tabi tutulamayacağ 1 bakış açısıyla şekillenmekteydi. Diğer bir tartışma alanı ise toplumsal olguları araştırmada metodolojik bir tavır olarak "araştırmacı ve değer" ilişkisi üzerineydi. Klasik düşünürlerin yaptığı çeşitli tartışmalarla; özellikle 60'lı yıllar ve sonraki süreçte, bilimsel bilgiye ve onun kaynaklarına dair görüşlerin farklılaşması ve çeşitlilik kazanmasıyla değer konusu sosyolojide önemli bir akademik ilgi alanı haline gelmiştir. Günümüzde değerler konusunda yapılmış birçok çalışma bulunmaktadır. Son elli yıllık süreçte, değerler alanında çalışmaların bu denli artış göstermesi şüphesiz toplumsal değişim ile yakından ilgilidir. Teknolojik gelişmelerle refah seviyesinin artması, aynı zamanda modernleşme süreci ile gündelik hayatımızın ve ilişkilerimizin yeniden şekil kazanması, değer konusunu önemli bir tartışma alanı haline getirmiştir. Öyle ki, ilgili literatür değerlendirdiğinde; özellikle gençlik kategorisinin değer algısı üzerine farklı akademik alanlarda yapılmış birçok çalışma göze çarpmaktadır. Diğer yandan, toplumsal ilişkilerin ideal ya da beklenilen şekliyle kurulabilmesinde önemli görülen, ancak giderek yozlaştığı düşünülen bazı değerleri eğitim yolu ile yeni nesillere aktarabilme gibi sosyal bir işlevi de önemseyerek, değerler eğitimi konusunda önemli bir literatürün bulunduğu görülmektedir. ${ }^{1}$ Değer konusunda Türkiye ölçekli yapılmış çalışmalar bile başlı başına araştırma konusu olabilecek nitelik ve niceliktedir. Türkiye'de yapılan çalışmaların 2000li yıllar sonrasından günümüze gösterdiği artış ivmesi, değerlerin gençlikteki karşılığına ilişkin kayg1 ve beklenti düzeylerini çıkarsayabileceğimiz bulgulara sahiptir. Fakat değişimin parametrelerini görebilmek adına, bilimsel çalışmalar üzerine analitik kıyaslamalar yapılması; bunu gerçekleştirirken de tarihselliğin

\footnotetext{
${ }^{1}$ Örneğin yaygın kullanılan akademik arama motorunda "değerler" kelimesini içeren başlığa sahip tüm zamanlarda yayımlanmıs yayınların sayısı ortalama 2300 civarıdır, bu çalışmaların neredeyse 2000'i 2000-2019 yılları arasında gerçekleştirilmiştir.
} 
gözetilmesi özellikle değer konusunun analiz çerçevesini genişletebilmek adına önemlidir. Sosyolojik açıdan değerlerin değişmesi şüphesiz kaçınılmazdır. Bu değişimin hızı, niteliği, etkileşim alanları ve gerçekleşme biçimi gibi bir takım özelliklerin analitik bir çerçevede ele alınması, gerçekte sosyolojik sonuçlar üzerine konuşabilmeyi mümkün hale getirir. Bu çalışmada 2000'li yılların hemen öncesinde yapılmış bir çalışmanın ölçme araçları, benzer araştırma kurgusu gözetilerek tekrarlanmıştır. Farklı zaman dilimlerinde elde edilen araştırma bulgularının analitik olarak karşılaştırılmasının yanı sıra yorum zeminini güçlendirebilmek adına, özellikle gençlik kategorisinde gözlemlediğimiz değişimin merkezi boyutları olarak; kurulan sosyal ilişkinin aktörleri, bu ilişkinin sıklığı ve sosyal medyanın kullanım düzeyleri ile değerler arasındaki ilişki çalışmaya dahil edilmiştir. Ayrıca bu çalışmada değişen eğitim sistemi ile beraber neredeyse fenomene dönüşen "üniversite sınavına hazırlanma süreci" de "gençliğin değerleri bu durumdan nasıl etkilenir?" sorusu ile göz önünde tutulmuştur. Bu bağlamda, sınava hazırlanma sürecinde; değerlerin yeniden inşa edildiği ve toplumsalın süzgecinden geçerek içselleştirildiği temel etkileşim yapıları olarak aile, akraba, arkadaşlarla ilişkileri ve sosyalleşme düzeyleri, önemsedikleri değerler çerçevesinde değerlendirilmeye çalışılacaktır.

\section{Değer Kavramı ve Sosyolojik Değeri²}

Gündelik ilişkilerimizde algılama tarzımıza etki eden, tutum ve davranışlarımıza yön veren, bu çerçevede sosyal etkileşimin normatif yapısını inşa ederek bir takım kurallarla organize edilmesini sağlayan değerler; sosyolojinin önemli konularından birisidir. Ancak burada "değer"e atfedilen önem sosyolojik düşünme geleneğinin her döneminde aynı olmamış, değerler konusu pozitivist bakış açısının etkisi ile sosyolojik araştırma alanının dışında tutulmak istenmişti. Metodolojik yaklaşımlar bir yana, aslında sosyolojinin bir bilim olarak kurgulanış bağlamı, değer dönüşümü ile çok yandan ilgiliydi. Ayrıca sosyolojinin merkezinde olan

\footnotetext{
${ }^{2}$ Bu başıık altında, çalışmanın merkezi tartışma alanını ve özünü unutturmayacak kadar sosyoloji ve değer ilişkisini ele almak istedik. Konu ile ilgili kapsamlı bir tartışma, bu çalışmanın asıl ilgisi dışında olduğu için sosyoloji ve değer konusunda öne çıkan düşünürlerin fikirlerine kısaca yer verildi.
} 
toplumsal düzen ve toplumsal eyleme ilişkin tartışmalarda "toplumsal değerler" merkezi rol oynamaktaydı. Burada kurucu isimler hatırland1ğında; öncelikle Comte'un düşüncesinde değerlere biçilen rol “toplumsal düzenin sağlanması veona rehberlik edilmesi"ndeahlaki düzlemde ele alınmıştır. Düzenin devamlılığı, içerisinde bağlanmanın, aktarımın geliştiği, insanlığa duyulan sevginin temellerinin atıldığı aile gibi temel kurumlar ise bunun taşıyıcısıdır. Durkheim ise neredeyse sosyolojinin kendisini, modernleşme ile birlikte değişen toplumsal yapının sorunlarına çare arayan dolayısıyla da değer dönüşümünü ve bunun sorunlarını konu eden bir bilim dalı olarak kurgulamıştır. Ahlaki değerler ise, dönemin atmosferi doğrultusunda Durkheim'in teorik kurgusunda merkezi önem taşır.Toplumsala olan vurguyla; örneğin dayanışma değerinin topluluk için faydalı yönlerine değinmektedir. Bir bilim olarak sosyolojinin doğuş bağlamı ve coğrafyası düşünüldüğünde, aydınlanma ile beraber 19. Yüzyıla kadar gelinen süreçte, toplumsal sorunların sebebi olarak görülen ahlaki çatışmalar dolayısıyla konu ettikleri ahlaki değerler, dönemin düşünürleri için önemli bir referans olmuş gözükmektedir. Bu dönemde ahlaki değerler, düzeni sağlaması ya da toplumu kurtuluşa erdirmesi için geri çağırılmıştır (Bkz. Splates, 1983; Özensel, 2003; Pickering, 2009; Birekul ve Alkın, 2015, Aksan, 2016; Ersoy, 2018).

Değerler ve sosyoloji ilişkisinde adı önemle anılması gereken düşünür ise MaxWeber'dir. Metodolojik yaklaşım konusunda her ne kadar araştırmacılara "değerlerden bağımsız" bir sosyolojinin icrasını önerse de, değer toplumsal olgulara bakış açısını şekillendiren önemli bir kaynaktır. Konuyla ilgili bilinen en önemli örnek, Weber'in (1999) dinsel eğilimlerin ekonomik davranışa etkisini konu ettiği çalışması çerçevesinde; dini değerler ve iktisadi değerler ilişkisidir. Diğer yandan,toplumsal eylemi anlama ve açıklama çabasında, aktörün eyleme atfettiği anlamın toplumsal bağlamla çakıştığı her nokta aslında sosyolojinin değer ile ilişkisini de açlk etmektedir. Onun düşüncesinde toplumsal eylem, aktörün hem kendisinin öznel bir anlam katarak; aynı zamanda diğerlerinin davranışlarını da dikkate alarak yönelttiğimiz eylemdir (Weber, 2012). Böylelikle değer hem davranışı belirleyen hem de davranışı karşılıklı ilişkiler çerçevesinde şekillendiren bir olgu olmaktadır.

Farklı bir tartışma ise en önemli klasiklerden Karl Marx tarafından yapılmıştır. Çoğu sosyolog, toplumsal araştırmaların değerlerden ayrışa- 
rak yapılabilirliğine dikkati çekerken Marx; diyalektik çözümleme içerisinde toplumsal değerlerin olgulardan ayrılamayacağını, kaldı ki böyle bir talebin de arzu edilir bir şey olmaması gerektiğin düşünmektedir. Değerleri toplumsal dünyanın araştırılması dışında tutmak olanaksızdır, bunu istemek de yersizdir. Çünkü değeri saf dışı bırakmak demek, insanların karşılaştıkları sorunlarında onlara cevap veremeyen, yardım etmeyen, tutkusuz, insanca olmayan bir sosyoloji üretecektir(Ritzer, 2011, s.46.).Burada toplumsal olguların değerlerden bağımsız olmadığı vurgu$\mathrm{su}$, sosyolojinin doğası gereği değerleri kendisinden ayıramayacağının ifadesidir.

Simmel (2014) ise toplum bilimsel araştırmada araştırıcının kendi değerleri konusunda takınacağı tutum tartışmalarının ötesinde, toplumsal ilişkilerde değerin yerine odaklanarak, bunun sosyolojik temeli için önemli bir altyapı sunmuştur. Simmel (2014, s.23, 24); değerler ve gerçeklik arasında doğrudan ilişki kurarak, onları kavramlarmmıın kendileri aractlığı ile dünya imajları haline geldiği karşılıklı bă̆ımsız kategoriler olarak değerlendirmektedir. Nesnelerin, düşüncelerin ve olayların değeri asla onların doğal varoluşlarından ve içeriklerinden çıkartılamaz. Bunların değere göre dizilişleri, doğal düzenlenişlerinden büyük ölçüde ayrilır. Ancak yanlış bir yorumdan; değere ilişkin kavramların doğal süreçten tamamen ayrı oluştuğu fikrinden kaçınılmalıdır. Mekanik bir nedensel sistem olarak, doğa için değer kavramlarının anlamı yok iken değerleri bilincimizin bir parçası haline getiren psişik tecrübeler gerçekte doğal dünyaya aittir. Dolayısıyla değerler dünya görüşünün kapsayıcı bir formu ve kategorisi olarak varlığa anlam katan, onları belirli kategoriler şeklinde anlamamızı sağlayan olgulardır. Diğer taraftan Parsons'un sosyolojik yaklaşımında değer meşru ve bağlayıcı olarak kabul edilen seçilmiş eylemlerimizin sonuçlar ile anlam ölçütleri olarak sosyal düzenin ona bağh olduğ $u$ bir çerçeve çizmektedir. Bu açıdan bireysel ve sosyal sistemlerin başarısı ile sosyalizasyon süreci yoluyla içselleştirilen değerlerbir biriyle bağlantılıdır (Abercrombie, Hill ve Turner, 1984, s.227).

Thomas ve Znanieckinin(1918) “Avrupa ve Amerika'da Polonyalı Köylü" isimli çalışması, değerlerin sosyolojik araştırma konusu olabilmesinin önünü açan neredeyse en önemli çalışmadır. O yıllarda "tutum", naturalistik yaklaşımın etkisi ile öncelikle içgüdü doğumla gelen biyolojik bir özellik olarak ele alınmaktaydı. Thomas ve Znaniecki'inin 
buradaki çabası takdire değerdir. Araştırmacılar öncelikle tutum kavramını biyolojiden ayırarak onun sosyolojik yönlerini açığa çıkarmaya çalışmışlardır. Ancak bunun pozitif bir teori olarak inşa edilmesi, sosyal yapı kavramı üzerinden ele alınması ile mümkündü. Bu noktada iseDurkheim'ın kollektif bilinç yaklaşımı etkili olmuştu. Böylelikle değerler, sosyal yapı ve kültürün her ikisinin de kendisini içerdiği anlamlı unsurlar olarak kullanıma sunuldu (Wiley, 1986, s.29,30). Thomas ve Znaniecki; bir değeri, "bazı sosyal grupların üyelerinde bulunan ampirik bir içeriğe sahip herhangi bir referans noktası ve eylemin amacına ilişkin bir anlam" şeklinde tanımlamaktaydı. Dolayısıyla, bir gida maddesi, bir enstrüman, bir madeni para, bir şiir parçası, bir üniversite, bir efsane, bilimsel bir teori" bir toplumsal değer olabilirdi (akt. Karslı, 2016, s.1605).

Peki "değer" dediğimiz şey tam olarak neyi ifade etmektedir? Kavramın sözlük anlamına bakıldığında Türk Dil kurumunun tanımlaması şu şekildedir: "Bir şeyin önemini belirlemeye yarayan soyut ölçü, bir şeyin değdiği karşılık, kıymet”. İkinci düzey karşıllğ̆ ise; bir şeyin para ile ölçülebilen karşılığı, bedel, kıymet, paha" şeklindedir. Burada varlıklara anlam verebilmemizi sağlayan soyut ölçüt olma ve aynı zamanda öneme atfen ölçülebilen bir karşılığa sahip olma anlamlarının belirginleştiği görülmektedir. Sosyolojik tanımlarda ise değerlerin; açık veya örtük biçimde, bireyin kendine özgü ya da grubun bir karakteristiği olarak; arzu edilir, seçilmiş eylemin biçimi, anlamı ve sonuçları ile anlam kazanan (Kluckhohn, 1951, s.395, Abercrombie, Hill ve Turner, 1984, s.227,) toplumsal bir veri tipi şeklinde; güçlü, yarı kalıcı, birleştirici ve bazen belirsiz eğilimleri yansittı̆̆ 1 ifade edilmektedir. Ancak değerler,sosyal eylemi somutlaştıran önemli bir motivasyon olarak sadece "arzu edilen şeyleri" yansıtmamakta, aynı zamanda bireysel bedeli olan ve anlık çıkarlara rağmen sürüp giden sosyal bir bağlama atıfta bulunmaktadır(vonScheve, 176, s.2015). Bireylerin toplumsal ve siyasal uzlaşısını şekillendirerek ortaklaşa paylaşılan bir alan sunan değerler konusunda belirli bir tutarlılık ve homojenlik de gerekli kabul edilmektedir. Özellikle toplumsal düzenin korunabilmesi ve sürdürülebilmesinde, uzlaşma kuramcılarının "bu ortaklaşa paylaşılan alanı inşa eden ortak değerlerin önemi"ne vurgu yaptığ1 görülür (Marshall, 1999, s.134). Bu çerçevede değerler; içinde bulunduğumuz grup için de güçlü biçimde hissedilen ve 
duygusal sorumluluk hissi uyandıran yargı ölçütleri olarak amaçlarımız ve eylemlerimizde varlık gösteren, davranışlarımızın genelleşmiş ilkelerini anlatır (Theodorson-Theodorson 1969, s.455). Değerleri tanımlayan bu yönler aynı zamanda kavramın sosyolojik değerini de gösterir. Böylelikle toplumsal ilişkilerde merkezi öneme sahip olan değer konusu, sosyolojik anlama ve açıklama pratiğinin en önemi anahtar kavramlarından birisidir.

\section{Değer Çalışmaları: Öncü ve Güncel Eğilimler}

Değerlerin toplumsal ilişkilerdeki anlamı, yeri, önemi ve işlevine dair teorik tartışmaları içeren, aynı zamanda "araştırmacının değer yargıları" konusunda fikir sunan ana eksen çalışmalardan günümüze, özellikle toplumsal değerler konusunda alan bulgusu içeren birçok çalışma bulunmaktadır. Literatür incelendiğinde, süreç içerisinde farklı değer grupları çerçevesinde değişik toplumsal kategoriler ve değişkenlerle analiz edilerek, öncü çalışmalardan bu yana gelişen geniş değerler literatüründe sıkça adı geçen temel çalışmalar; Kluckhohn (1951), Allport, Vernon ve Lizdey(1960), Rokeach (1968, 1973), Inglehart (1976; 1977; 1982; 1997), Schwartz ve Bilsky (1987; 1990), Schwartz (1992)'ın çalışmalarıdır.

1918 yılında Znaniecki ve Thomas'ın sosyal bilimlere kazandırdığ 1 değerler konusunun tespitine yönelik ilk test, Spranger (1928) tarafından gerçekleştirilmiştir. Spranger(1928) şahsiyet yapılarını analiz ederek, insanların buna göre altı değer kategorisinden birisine girebileceği belirtmiştir. Onu izleyerek bu çalışmayı daha geniş çerçevede ele alan (Ersoy, 2018, s.362) Allport, Vernon ve Lizdey(1960) altı temel kategoride siyasi, sosyal, ekonomik, dini, estetik ve bilimsel olarak değerleri sınıflamışlardır. Bahsedilen boyutlar, bireylerin değersel varlık alanını ifade etmektedir. Araştırmacıların bu boyutları ölçeğe dönüştürdükleri çalışmaları, değerlerin ölçülmesi konusunda önemli bir başvuru kaynağıdır. Rokeach (1973) ise tutum ve değer ayrımında, amaç ve araç olma bakımından sınıflama ile değerlerin bireysel ve sosyal boyutlarını vurgulamıştır. 80'li yıllar sonrasında yapılan araştırmalar ise değer kategorizasyonunu daha sistemli ve analitik biçimde genişleterek uluslararası düzeyde gerçekleştirilmiş çalışmalardır (Topçuoğlu1999, s.18). Inglehart 
(1982, 1997) ve Schwartz'in( ve Bilsky 1990, 1992, 2001) çalışmaları buna örnek verilebilir.

Inglehart (1997) 43 farklı ülkenin verisi üzerinden gerçekleştirdiği çalışmasında kültürün bağlayıcı yönünden hareketle, değerlerin ekonomik ve teknolojik gelişmelerle etkileşimine, dolayısıyla modern ve postmodern farklılaşmaya dikkati çekmektedir. Schwartz(1992) ise kültürlerarası farklılıklar çerçevesinde oluşturulan 10 farklı değer kategorisini test ettikleri çalışmasında, daha geniş bir bağlam içerisinde temel değerleri ölçmeye çalışmıştır. Burada bireylerin değer önceliklerinin sosyal deneyimlerinden nasıl etkilendiği; ortak sosyal konumlar sebebiyle oluşan (ör. yaş, cinsiyet, meslek gibi) ortak deneyimlerin ve (travma, ebeveynlerle ilişkiler, göç gibi) benzersiz deneyimlerin değer önceliklerini nasıl etkilediği ve siyaset, ideolojinin ve dinin değer öncelikleri ile ilişkisi gibi geniş çerçevede etkileşim yapıları değerlendirilmiştir. Schwartz, sonrasında farklı bir araştırmacı grubuyla gerçekleştirdiği çalışmasında (Schwartz vd., 2011) ise İtalya, Güney Afrika ve Uganda gibi bazı bölgelerde ortaya çıkan ölçme sıkıntıları sebebiyle Schwartz Değerler Ölçeğinde bir takım değişikliklerle (örneğin ölçme derecelerini 7 den 6 dereceye düşürülmesi, bazı değer ifadelerinin açılayıcı belirtilmesi gibi) güçlendirilmiş bir değerler ölçeği oluşturmuşlardır. Ancak aynı çalışmaya göre; değerlerin ölçülmesinde Schwartz Değerler Ölçeğinin halen güçlü açıklama kapasitesine sahip olduğu belirtilmiştir.

Değer konusu öncelikle klasik sosyolojinin tartışma konularında gündeme gelmiş, değerlerin ölçülmesi, değer ifadelerinin ve bunu çerçeveleyen değer gruplarının belirlenmesi ise 1950'li yıllardan sonra çoğunlukla psikolog ve sosyal psikologların katkısıyla gerçekleşmiş görünmektedir. Türkiye'de ise; Hilmi Ziya Ülken'in $(1965,1966)$ değer konusu ile ilgili gerçekleştirdiği teorik tartışmaların yanı sıra; 1972 yılında Kağıtçıbaşı'nın İzmir Lise Gençliği üzerine yaptığı araştırması, Erol Güngör'ün 1993 tarihli ahlaki değerleri ölçen saha araştırmasını içeren Değerler Psikolojisi isimli çalışması, Gökçe'nin(1994) Türk Gençliğinin Sosyal ve Ahlaki Değerleri isimli çalışması, Abdullah Topçuoğlu'nun 1999 yılında Konya ve Ankara'da gerçekleştirdiği Üniversite Gençliğinin Değerleri isimli çalışmayla birlikte Ergüder, Esmer ve Kalaycıŏglu'nun 1991'de TÜSİAD'ın desteklediği Türk Toplumunun Değerleri isimli çalışması değer konusu ile ilgili yapılmış öncü çalışmalar olarak değerlendirilebilir. Ampirik ilk 
çalışmaların yapıldığı 70'li yıllardan günümüze, değerler alanında oldukça zengin bir literatür oluşmuştur. Psikoloji, sosyoloji, antropoloji alanlarının yansıra eğitim bilimleri ve ilahiyat alanındaki çalışmalar ${ }^{3}$ özellikle değerler eğitimi tartışmaları ile ivme kazanarak ilgili literatürü geliştirmiştir. Bu çalışmanın asıl ilgi odağı olarak gençlik, üniversite gençliği ve değerler ilişkisi konusunda yapılan bazı güncel çalışmalara ve bulgularına kısaca aşağıda değinilmiştir.

\section{Araştırma Deseni ve Yöntem}

Değerler konusunun ölçülmesinde gençlik önemli bir kategoridir. Bunun temel sebebi ise genel olarak teknolojik ve küresel gelişmelerle ifade bulan geç modernliğin ${ }^{4}$ sebep olduğu hızlı değişim ve dönüşümün, ergenlik ve yetişkinlik arasında geçişte, kimlik karmaşasının ve bunalımının yaşandığı duygusal olarak yoğun ve çalkantılı bir dönem olan gençlik dönemini daha kırılgan hale getirmesidir. Üniversite gençliği ise genellikle 18 ve 24 yaş aralığında; aldıkları eğitim ile siyasal, sosyal, kültürel, teknik birçok alanda toplumun geleceğinin inşasını sağlayacak olmasına umut bağlanmış akademik bilgi ve donanıma sahip kitledir. Gençlik kategorisinde konu ile ilgili yapılmış birçok araştırma bulunmaktadır. Örneğin Helve tarafından 2015 yılında yayınlanmış bir çalışmada Finlandiya'da,vatandaşlık tipleri ve değerler arasında ilişki kurularak gençliğin değerlerini konu edinmiştir. Sosyolojik bir araştırmada değerin etkileşim alanlarını görebilmek adına önemli veriler sunan bu çalışmada, 1989 yılından 2011'e bazı dönemlerde yapılmış çalışmalar 4 faza ayrılarak incelenmiştir. Kısaca bireyciler, fütüristler, gelenekçiler, çeoreciler, kinikler, neoliberaller, küreselleşmeciler, ulusalcılar gibi birçok farklı kategori oluşturularak bu kategorilerin sosyal sermaye, kimlik, vatandaşlık, gençlik politikaları gibi farklı alanlarla ilişkileri analiz edilmiştir. Buradaki temel bulgu, Finli gençlikte ekonomik durgunluğa rağmen post materya-

\footnotetext{
${ }^{3}$ Konu ile ilgili literatür incelemesi için bkz. İsmail Akyüz, Türkiye'de Gençlik, Din ve Değerler Konusunda Yapılan Ampirik Araştırmaların Yöntem Ve lç̧erik Analizi. Sakarya Üniversitesi Ilahiyat Fakültesi Dergisi, XVII(30), 1-20.

${ }^{4}$ Giddens'ın, küresel ve teknolojik gelişmelerin etkisiyle modern dünyada artan riskleri ifade etmek ve yeni toplumsal durumu postmodern olarak adlandırmaya tercih ettiği kavram ve teorik arka planı için bkz. Giddens, A. (1998). Modernliğin sonuçları. İstanbul: Ayrıntı Yayınları.
} 
list değerlerin azalma eğilimi göstermesi olmuştur. Farklı bir güncel çalışmada ise gençlik, sosyal değişim, çeşitlilik ve kimlik konuları değerler çerçevesinde ele alınmıştır (Thomson ve Holland, 2004). Görüşme, odak grup ve alan araştırması verilerinden hareketle "gençliğin değerleri" sistemleştirilmeye çalışılmış, cinsel değerler, yaşam değerleri, çevresel değerler, kişisel ilgi değerleri, güven ve bireylerarası değerler gibi farklı alt boyutlar; yaş, etnisite, cinsiyet, yer gibi farklı bağımsız değişkenlerle değerlendirilmiştir. Çalışmada genç bireylerin olgunluk, otonomluk ve sosyalleşme gibi içeriklere sahip bireyselleştirilmiş yetişkinlik modeli ve başkalarına karşı bakım yükümlülükleri gibi konuları içeren sosyalleştirilmiş yetişkinlik modeli arasında gerilim yaşadığı bulgulanmıştır.

Ülkemizde 2009 yılında yayınlanan Coşkun ve Yıldırım'ın üniversite gençliğinin değerlerini, bazı değişkenler açısından inceledikleri araştırmada adalet-sayg1 ve yardımseverlik' 'maddi dürüstlük' ve 'doğru sözlülük' gibi ölçek alt boyutları değerlendirilmiştir. Çalışmaya göre kadın üniversite öğrencilerinin değer puanları erkeklere göre daha yüksek düzeyde bulunmuş, fakülteler arası farklılaşmalar olduğu tespit edilmiştir. Öngen ve Aytaç'ın çalışması ise (2013) üniversite öğrencilerinin toplumsal cinsiyet rollerine ilişkin tutumları ve yaşam değerleri ilişkisine odaklanmaktadır. Çalışmada Allport, Vernon ve Lindzeyn'in (1960) belirlemiş olduğu altı değer boyutuna Güngör'ün (1998) ahlaki değer boyutunu da ekleyerek geliştirdikleri ölçek kullanılmıştır. Evlilik cinsiyet rolü ve eşitlikçi cinsiyet rolü ile yaşam değerleri arasında anlamlı ve olumlu yönde korelasyon ilişkisi tespit edilmiştir. Kıran'ın 2016'da yayınladığı araştırmasında ise; üniversite öğrencileri arasında davranışlara yön verme bakımından en fazla önemin özaşkınlık değerlerine verildiği, sonrasında da muhafazacı değerlerin önemsendiği tespit edilmiştir. Gençler arasında en az önem verilen değer tipinin ise yeniliğe açıklık değer tipi olduğu saptanmıştır (Kıran, 2016).

Üniversite gençliği ve değerler çerçevesinde yapılan başka bir çalışma ise üniversite öğrencilerinin öz-anlayışıları ile değer tercihlerini incelenmesi konuludur. Dilmaç ve diğerleri (2009), Schwartz'ın değerler ölçeğini kullanarak bazı sonuçlara ulaşmıştır. Hazcılık alt boyutunda kız öğrenciler ile erkek öğrenciler arasında anlamlı bir farklılık bulunmuştur. $\mathrm{Bu}$ fark erkek öğrencilerin lehinedir. Çalışmada öz denetim, yardımseverlik, uyum, güvenlik alt boyutları ortalamaları da kız öğrencilerin lehine bir 
durum göstermiştir. Farklı bir çalışma ise dindarlık ile değerler ilişkisini konu etmiştir. Mehmedoğlu'nun (2006) gerçekleştirdiği araştırmanın bulguları, ilâhiyat fakültesi öğrencilerinin, iyilikseverlik, güvenlik ve uyma değerlerine yüksek; hazcllık ve uyarılım değerlerine ise daha düşük önem verdiğini göstermiştir. Dindarlık ise gelenek, iyilikseverlik, uyma, başarı, evrenselcilik ve güvenlik değerleriyle anlamlı pozitif; hazcıllk değeriyle ise anlamlı negatif ilişkili olduğunu ortaya koymuştur. Dindarlık ve değerler ilişkisinde Özcan ve Erol'un (2017) çalışmasının bulgularına göre öğrencilerin değer yönelimleri genel olarak toplum merkezli değerler yönünde olurken, birey merkezli değerlere ise daha az önem atfedildiği görülmektedir. "Dinin etkisini hissetme" ve değerler arasındaki ilişkiye bakıldığında ise muhafazakârlık değerleriyle pozitif, yeniliğe açıklık değerleriyle ise negatif yönde anlamlı ilişkilerin bulunduğu tespit edilmiştir.

Değerler ve üniversite gençliği konulu ulaşılabilen en güncel çalışma ise Ulu'nun (2018) psikolojik iyi oluş ile değerler arasında ilişkiye odaklandığ1 araştırmasıdır. Farklı üniversite örneklemi ile gerçekleştirilen araştırmanın bulgularına göre; değer yönelimlerinde özyönelim, uyarılma, hazcllk, güvenlik, uyma, iyilikseverlik ve evrenselcilikte kadınların; güçte ise erkeklerin ortalama puanlarının anlamlı olarak daha yüksek olduğu; psikolojik iyi oluş toplam puanı ile özyönelim, uyarılma, hazcıllk, başarı, güvenlik, uyma, geleneksellik, iyilikseverlik ve evrenselcilik arasinda pozitif yönde anlamlı bir ilişki olduğu tespit edilmiştir.

Genel olarak değerlendirildiğinde; uluslararası literatürde gençlik ve değer ilişkisindeki güncel çalışmalar genellikle sosyal değişme, sosyal sermaye, vatandaşlık, demokratik tutumlar ve kimlik ile değerler ilişkisi kurarken ülkemizde, toplumsal cinsiyet konusu ve dindarlık gibi psikolojik tutumlarla ilişkilendirilen çalışmaların gerçekleştirildiği görülmektedir. Bilindiği üzere 20 yılda birçok farklı toplumsal alanda değişmeler yaşanmıştır. Bu durumun gençliğin değerlerine yansıması şüphesiz teorik ve sahaya dayalı sosyolojik yorumlarla da desteklenebilir. Bu çalışma ise aslında Topçuoğlu'nun 1999 'da yayımladı̆̆ı; üniversite gençliğinin değerlerini kurumların önemi ile karşılaştıran araştırması ile neredeyse benzer ölçme araçları kullanılarak 2018 yılında gerçekleştirilen araştırma bulgularını kıyaslamayı amaçlamaktadır. Ayrıca çalışmada üniversite sınavına hazırlanma süreci önemli bir parametre olarak düşünülmüş, bazı sorularla "bu sürecin değerlerin içselleştirilmesine etkisi olabilir mi" 
sorunsalı üzerinden veriler anlaşılmaya çalışılmıştır. Önceki çalışma ile değer alt boyutları, genel olarak büyük ölçüde örtüşse de her iki çalışma için farklı ayrışmalar üzerinden yorum yapılmasına karar verilmiş, k1yaslanacak temel bulgu ise ikinci seviye faktör alt boyutlarının korelasyon ilişkileri olmuştur. Bunların yanı sıra cinsiyet, bölüm, anne eğitim ve baba eğitim düzeyinin değer yönelimleri ile ilişkileri değerlendirilerek genel bulgular üzerinden kıyaslamalar yapılmıştır.

\section{Araştırmanın Örneklemi}

Araştırmanın evreni Konya'dır. Önceki çalışmada görüşülen kişiler Selçuk Üniversitesi ile ODTÜ'den seçilmişti (Topçuoğlu, 1999). Bu çalışmada ise 20 yıl sonrasında Selçuk Üniversitesinin daha yoğun ve heterojen bir gençlik profiline sahip olduğu gözlem verisi göz ününde tutularak farklı bir şehirdeki üniversite ile kıyaslama yapılmamıştır. Ancak çalışmanın merkezi "değerler" olduğu için "devlet- vakıf üniversitesi öğrencileri arasında değer yönelimlerinde belirgin bir farklılaşma var mıdır?" sorusu önemsenmiş, örneklem biri devlet biri özel olmak üzere 2 farklı üniversiteden seçilmiştir. Saha araştırması 2017-2018 akademik takvimin bahar yarıyılında gerçekleştirilmiştir. Öğrenciler seçilirken cinsiyet ve sınıf kotaları göz önünde bulundurularak kotaların kendi içlerinde hemen hemen eşit sayılara ulaşılmaya çalışılmıştır. Vakıf üniversitesi ile tam örtüşme olmadığı için fakülte üzerinden kotalı bir seçim yapılamamıştır. Devlet üniversitesinde mühendislik, hukuk, mimarlık, iletişim, iktisadi ve idari bilimler gibi alanlardan seçilmiş, vakıf üniversitesinden ise bazı durumlarda fakülte bazında olamasa da, bölümlerin örtüşmesi önemsenmiştir. Bu doğrultuda örneklem 927 kişi olarak belirlenmiş, 653 Selçuk, 274 Karatay Üniversitesi öğrencisinin verdiği cevaplardan elde edilen veriler değerlendirilmiştir.

\section{Veri Toplama Araçlar}

Çalışmada demografik sorular ve üniversite hazırlanma sürecinde ders çalışma süreleri ve sosyal ilişki düzeylerini ölçmeye yarayan sorular, 6 ve 10 dereceli dini inanç düzeyi ve dindarlık ölçekleri kullanılmıştır. Kullanılan ölçekler ise Topçuoğlu'nun (1999) araştırmasında kullandı̆̆ı; 
kurumların değeri ölçeği ile Rokeach (1973) ile başlayan ve Schwartz tarafından sürdürülen sistemli araştırmalar dizisinden "Değerlerin İçerikleri ve Yapısındaki Evrensellikler" isimli çalışmasında geçen değer ifadeleridir. Değerler listesinde her bir değerin ne derece önemli olduğunu, dolayısıyla da benimsendiğini anlamak için "önemli" ve "önemsiz" ikili kutupta, tek boyutlu 7'li anlam ayrıştırımı ölçeği kullanılmıştır(Bkz. Osgood, Suci ve Tannenbaum, 1957). Kurumların değeri ise beşli Likert tipi ölçek kullanılarak ölçülmeye çalışılmıştır.

Tablo 1. Schwartz Değerler Ölçeği ve Kurumlarn Değeri Ölçeğine Ait Güvenilirlik Analizi

\begin{tabular}{lcc}
\hline Ölçek & Cronbach's Alpha & Madde sayısı \\
\hline DYÖ(1992) & 0,945 & 57 \\
\hline KDÖ(1999) & 0,944 & 46 \\
\hline
\end{tabular}

Değerler Yönelimleri Ölçeği (DYÖ) 57 değer ifadesini içermektedir. Daha önceden farklı çalışmalarda sıkça kullanılan ölçeğin (Topçuoğlu, 1999; Kuşdil ve Kağıtçıbaşı, 2000; Çalışkan ve Karademir, 2014) bu çalışmada da analize uygun olup olmadığının tespiti için Güvenilirlik Analizi yapılmıştır. Cronbach Alfa Katsayısına bağlı olarak bu çalışmada kullanılan değerler ölçeğinin güvenilirlik katsayısı $\alpha: 0,945$ olarak yüksek derecede güvenilirdir. Kullanılan diğer bir ölçek ise Kurumların Değeri Ölçeği'dir (KDÖ) (Topçuoğlu, 1999). Analize göre bu ölçek de yüksek derecede güvenilirdir. 46 kurum ifadesinden oluşan ölçeğin güvenilirlik katsayısı $\alpha$ : 0,944'tür.

\section{Demografik Veriler}

Araştırmaya katılan toplam 927 kişinin demografik verileri Tablo 2'de gösterilmektedir. Buna göre araştırmanın örneklem seçiminde önemsediği kriter olarak eşite yakın sayılarda cinsiyet ve sınıf dağılımı görülmektedir. Katılımcılar en çok hukuk fakültesi öğrencisidir. Bu sayının yüksek olması, devlet ve vakıf üniversitesinde bu bölümün örtüşmesi ile ilgilidir. Geri kalanlar oransal dağılımda sırasıyla;ïBF- İşletme ve Yönetim, Mühendislik, Mimarlık ve Güzel Sanatlar, İletişim, Tıp ve Diş Hekimliği, Edebiyat ve Sosyal ve Beşeri Bilimler Fakültelerindendir. Mezun 
olunan okul çok büyük oranda Anadolu Liseleridir. Anadolu liselerinin geçtiğimiz birkaç yıl içinde çok daha yaygın hale gelmesi, bu oranı açıklamaktadır. Katılımcıların çok büyük bir kısmı, hayatlarının en uzun kısmını şehir ve büyük şehirlerde geçirmiştir. Dolayısıyla bu çalışmanın üniversite gençliği, genel olarak kent karakterlidir.

\section{Tablo 2. Demografik değişkenler}

\begin{tabular}{|c|c|c|c|}
\hline & & Frekans & Yüzde \\
\hline \multirow[t]{2}{*}{ Üniversite } & Devlet & 653 & 70,4 \\
\hline & Vakıf & 274 & 29,6 \\
\hline \multirow[t]{3}{*}{ Cinsiyet } & Kadın & 488 & 52,6 \\
\hline & Erkek & 439 & 47,4 \\
\hline & Birinci sinıf & 250 & 27,0 \\
\hline \multirow{4}{*}{ Sinıf } & İkinci sınıf & 202 & 21,8 \\
\hline & Üçüncü sınıf & 242 & 26,1 \\
\hline & Dördüncü sınıf & 233 & 25,1 \\
\hline & İ̈BF-İşletme ve Yönetim & 154 & 16,6 \\
\hline \multirow[t]{8}{*}{ Fakülte } & Hukuk & 203 & 21.9 \\
\hline & Mimarlık- Güzel Sanatlar & 134 & 14,5 \\
\hline & Mühendislik & 152 & 16,4 \\
\hline & İletişim & 120 & 12,9 \\
\hline & Edebiyat- Sos. ve Beş. Bil. & 95 & 10,2 \\
\hline & Tıp ve Diş Hekimliği & 69 & 7,4 \\
\hline & Fen lisesi & 54 & 5.8 \\
\hline & Anadolu Lisesi & 471 & 50,8 \\
\hline Mezun & Normal lise & 181 & 19,5 \\
\hline \multirow[t]{3}{*}{ Olunan Lise } & Meslek Lisesi & 101 & 10,9 \\
\hline & İmam Hatip Lisesi & 120 & 12,9 \\
\hline & Köy & 60 & 6,5 \\
\hline \multirow{4}{*}{$\begin{array}{l}\text { En uzun süre } \\
\text { yaşanılan } \\
\text { yerleşim yeri }\end{array}$} & Kasaba & 30 & 3,2 \\
\hline & İlçe & 154 & 16,6 \\
\hline & Şehir & 323 & 34,8 \\
\hline & Büyükşehir & 360 & 38,8 \\
\hline \multirow{6}{*}{$\begin{array}{l}\text { Anne } \\
\text { eğitim } \\
\text { düzeyi }\end{array}$} & Okuryazar değil & 41 & 4,4 \\
\hline & Okuryazar & 32 & 3,5 \\
\hline & İlkokul & 317 & 34,2 \\
\hline & Ortaokul & 162 & 17,5 \\
\hline & Lise & 238 & 25,7 \\
\hline & Üniversite & 129 & 13,9 \\
\hline \multirow{6}{*}{$\begin{array}{l}\text { Baba } \\
\text { eğitim } \\
\text { düzeyi }\end{array}$} & Okuryazar değil & 4 & 0,4 \\
\hline & Okuryazar & 11 & 1,2 \\
\hline & İlkokul & 164 & 17,7 \\
\hline & Ortaokul & 165 & 17,8 \\
\hline & Lise & 284 & 30,6 \\
\hline & Üniversite & 264 & 28,5 \\
\hline \multicolumn{2}{|c|}{ Günlük ortalama internet kullanımı } & $2-5$ saat & 454 kişi (\%49) \\
\hline
\end{tabular}


Anneler en çok ilkokul mezunu iken babalarda lise ve üniversite mezunu olma oranı çok daha yüksektir. Önceki çalışma ile kıyaslandığında; ebeveynlerde okuryazarlığın arttığı, fakat anne eğitim düzeyinde yine de ilkokul mezunu olan annelerin oranının yüksek olduğu görülmektedir. Önceki çalışmada üniversite mezunu annelerin oranı çok daha fazladır(Topçuoğlu, 1999). Öncesinde üniversite eğitimi, çoğunlukla eğitim seviyesi yüksek kişiler için daha değerli ve erişilebilir iken 20 yıllık süre zarfında üniversite eğitimini önemli görme eğilimi, eğitimli eğitimsiz her anne baba için (biraz da kurtuluş yolu görülerek) artış göstermiş görünmektedir. Babalar ise en çok lise mezunudur. 20 yıl sonrasında babaların da eğitim düzeyi artmıştır. İnternet kullanımları ise çoğunlukla 2-5 saattir. Bu durum 1-5 saat aralığında \%78lere ulaşmaktadır.

Tablo 3. Demografik değişkenlerde ortalama değerler

\begin{tabular}{llllll}
\hline & N & Minimum & Maximum & Ortalama & Std Sapma \\
\hline Devlet Üniversitesi & & & & & \\
\hline Yaş & 653 & 18.00 & 30.00 & 21,1792 & 1,78527 \\
Kardeş sayısı & 653 & 0.00 & 12.00 & 3,0597 & 1,71544 \\
Aylık hane gelir & 653 & $100 \mathrm{TL}$ & $20000 \mathrm{TL}$ & 3572,5881 & 2239,4657 \\
Aylık kişisel gelir & 622 & $100 \mathrm{TL}$ & $3500 \mathrm{TL}$ & 767,4502 & 410,62199 \\
Dindarlık düzeyi & 653 & 1 & 10 & 5,55 & 2,05728 \\
\hline Vakıf Üniversitesi & & & & & \\
\hline Yaş & 274 & 18.00 & 30.00 & 21,7007 & 1,98295 \\
Kardeş sayısı & 274 & 0.00 & 12.00 & 2,6533 & 1,71832 \\
Aylık hane gelir & 268 & $1000 \mathrm{TL}$ & $50000 \mathrm{Tl}$ & 6351,7537 & 6209,01666 \\
Aylık kişisel gelir & 229 & $100 \mathrm{TL}$ & $4000 \mathrm{TL}$ & 905,2183 & 654,72010 \\
Dindarlı düzeyi & 274 & 1 & 10 & 5.86 & 1,99634 \\
\hline
\end{tabular}

Tablo 3 değerlendirildiğinde, devlet üniversitesinde okuyanlar genellikle; ortalama 21 yaşlarında, üç kardeşi olan, hane geliri aylık $3500 \mathrm{Tl}$ civarında kişilerdir. Vakıf üniversitesinde okuyanlar ise devletle karşılaştırıldığında, yaş ortalaması daha büyük, kardeş sayısı daha az, gelir bakımından ise daha fazla toplam aylık gelir ortalamasına sahiptir. Her iki üniversite öğrencilerinin dindarlık ortalamaları birbirine yakın düzeydedir. Her iki üniversitenin aylık hane gelirinin maksimum düzeyi birbirinden oldukça farklıdır. 


\section{Bulgular}

Faktör analizinin kullanılma amacc, bilimsel bir amaç olarak, değişkenlerde karşılıklı ilişkileri doğru bir biçimde özetlemek ve kavramlaştırmaktır. Bunu da faktör analizi, asıl değişkenlerdeki maksimum bilgi miktarını birkaç faktörün içine sıkıştırarak başarır(Topçuoğlu, 1999, s.28). Karşılaştırmaya tabi tutulan ilk çalışma(Topçuoğlu, 1999) verileri incelendiğinde; değer yönelimleri ölçeği faktör yapıları; dindarlık ve gelenekçilik, sosyal güç ve itibar, özgecilik ve çevrecilik, uyum, maceracılık, maddi yaşam ve zevk, bilgelik ve araştırıcılık şeklinde ayrışmıştı. Bu çalışmada ilk çalışmanın ayrımlaşan faktör alt boyutları kullanılmamış, tekrar faktör analizi yapılarak, 20 yıl sonra ortaya çıkan yapılaşma farklılıkları değerlendirilmiştir. Kurumların değeri ölçeğinde de aynı yol izlenmiştir. Her iki ölçek, eski ayrışmalarla benzerlikler taşıyan yeni faktör grupları ile analiz edilerek bazı sonuçlara ulaşılmıştır.

\section{Ölçek Yapı Geçerliliği}

Faktör analizi yapilırken genel kural 300'den fazla örneklem üzerine gerçekleşmesinin yeterli olacağı yönündedir ${ }^{5}$. Dolayısıyla 927 katılımcı ile gerçekleştirilen bu çalışma faktör analizi için çok iyi bir örneklem sayısına sahiptir. Değer Yönelimleri Ölçeğinde; Scwartz'ın (1992) çalışmasında öngördüğü 10 faktör ayrımı ve Topçuoğlu'nun (1999) çalışmasında öngördügü 8 faktör ayrımı bu çalışmada öncelikle gözlenmemiş, ilk olarak ölçeğin 12 farklı faktöre ayrımlaştığı görülmüştür. Daha sonrasında bu ayrım Varimax rotasyona tabi tutulmuş, birbirine çok yakın yer ve düzeylerde, düşük faktör yüklemeleri ile ayrışan ifadeler çıkarılmıştır. Bu çalışmada toplamda öz değeri 1.000'den daha büyük olan 7 faktör bulunmuştur(Tablo 4). Bu ifadelerle yapılan analize göre Kaiser-MeyerOlkin (KMO) değeri 920, df 496 ve Sig. .000 olarak bulunmuştur. 7 faktör toplam varyasyonun \%56,651'ini açıklamaktadır. Önceki çalışmada her iki ölçeğe uygulanan ikinci düzey faktör analiziyle oluşturulmuş alt boyutlar ile bu çalışmada faktör analiziyle 3 boyuta yordanan alt boyutlar,

\footnotetext{
${ }^{5}$ Ayrıntılı bilgi ve referans kaynakları için bkz. Altunsu Sönmez\& Aksan, "Üniversite Öğrencilerinin Tolerans Düzeylerinin Farklı Değişkenlerle ilişkisi”, S.Ü. Sosyal Bilimler Enstitüsü Dergisi, 41, s. 302-316, 2019.
} 
ifadeler bakımından örtüştüğü için çalışma için kıyaslanabilir bulunmuştur. Bu sebeple bu araştırmanın faktör grupları 2. Seviye faktör analizine tabi tutulmamıştır.

Tablo 4. Değer yönelimleri ölçeği alt boyutları ve faktör yüklemeleri

\begin{tabular}{|c|c|c|c|c|c|c|c|}
\hline & 1 & 2 & 3 & 4 & 5 & 6 & 7 \\
\hline 7.Barış İçinde Bir Dünya & 691 & & & & & & \\
\hline 24.Güzelliklerle Dolu Bir Dünya & 650 & & & & & & \\
\hline 19.Eşitlik & 630 & & & & & & \\
\hline 23.Gerçek Dostluk &, 574 & & & & & & \\
\hline 18.Ebeveyn ve Yaşlılara Saygı &, 548 & & & & & & \\
\hline 6.Hoşgörülü Olmak & ,531 & & & & & & \\
\hline 34.Kendini Kontrol & & 772 & & & & & \\
\hline 33.Kendine Sayg1 & & 758 & & & & & \\
\hline 32.Kendi Yönünü Belirleyebilmek & & 699 & & & & & \\
\hline 36.Kontrol Gücü & &, 577 & & & & & \\
\hline 35.Kibarlık & & 476 & & & & & \\
\hline 15.Dindarlık & & & ,720 & & & & \\
\hline 31.Kabullenme(insanın kaderine razı olması) & & & ,705 & & & & \\
\hline 29.İtaatkarlık & & & 697 & & & & \\
\hline 37.Manevi Yaşam & & &, 547 & & & & \\
\hline 21.Gelenek ve Göreneklere Sayg1 & & & ,537 & & & & \\
\hline 30.İyiliklerin Ödenmesi & & & 474 & & & & \\
\hline 8.Başarılı Olmak & & & & ,764 & & & \\
\hline 9.Bilgelik & & & & ,711 & & & \\
\hline 10.Başarma hissi & & & & 676 & & & \\
\hline 3.Ak1llı Olmak & & & & ,634 & & & \\
\hline 49.Sosyal Adalet & & & & & 736 & & \\
\hline 50.Sosyal Düzen (toplumun istikrarlı olması) & & & & & 694 & & \\
\hline$\underline{45 . S a g ̆ l i k l ı ~ O l m a k ~}$ & & & & & 607 & & \\
\hline 48.Sorumluluk Sahibi Olmak & & & & & ,551 & & \\
\hline 46.Sevecen Olmak & & & & & & ,758 & \\
\hline 47.Ilımlı Olmak & & & & & & ,739 & \\
\hline 39.Neşeli Olmak & & & & & & 650 & \\
\hline 13.Değişik Bir Yaşam & & & & & & & ,741 \\
\hline 25.Heyecan Verici Bir Yaşam & & & & & & & 655 \\
\hline 14.D1ş Görünümü Koruyabilmek(İmaj) & & & & & & & 644 \\
\hline 26.Hırslı olmak & & & & & & & 463 \\
\hline
\end{tabular}

Değer yönelimleri ölçeğinin faktör maddeleri ve yük değerleri Tablo 4 'te gösterilmektedir. Buna göre; "barış içinde bir dünya, güzelliklerle dolu bir dünya, eşitlik, gerçek dostluk, ebeveyn ve yaşlılara saygı, hoş- 
görülü olmak" değer ifadelerinin ayrıştığı ilk faktör grubu "özgeci yönelim" olarak adlandırılmıştır. Diğer alt boyutlar; ikinci faktör alt boyutu "bireycilik yönelimi", üçüncü alt boyut "dindarlı ve manevi yönelim", dördüncü alt boyut "akılcr yönelim", beşinci alt boyut "toplumsal yönelim", altınc alt boyut "iyilik hali", son olarak yedinci alt boyut ise "uyaricllik yönelimi" olarak adlandırılmıştır. Önceki çalışmada(Topçuoğlu,1999, s.57); özgecilik ve çevrecilik faktör alt boyutunun benzer ifadelerle ayrıştığ 1 görülmüştür. Bazı ifadeler ise çok daha farklı faktör gruplarında yer almıştır. Örneğin önceki çalışmada(Topçuoğlu, 1999), hırsh olmak ifadesi; sosyal itibar, sosyal güç, otorite ve etkili olmak gibi sosyal yönü daha fazla ağır basan değer ifadeleriyle ayrışırken bu çalışmada yaşamı ya da yaşam tarzını niteleyen değer alt boyutu içerisinde yer almıştır. İlginç bir değişiklik de kibarlık değer ifadesi ile ilgilidir. Önceki çalışmada hayatın anlamı, sadık olmak, güzelliklerle dolu bir dünya gibi ifadelerin yer aldığ 1 uyum alt boyutunda ayrışan kibarlık değeri yeni araştırmada; öz kontrol, kontrol gücü, öz saygi ve yön belirleme ifadeleri ile gruplaşmıştır. Dolayısıyla kibarlığın yaşamın doğal bir yönü ile ilişkilendirilebilir tarafı dönüşerek daha bireyci bir karakter kazanmıştır.

Çalışmada kullanılan diğer ölçek, Kurumların Değeri Ölçeği'dir (Topçuoğlu, 1999). 46 kurum ifadesinden oluşan ölçeğin faktör analizinde, çok yakın yerlerde ve $0,4^{\prime}$ ün altında değerle ayrışan ifadeler(kahramanlık, hükümet, şirketler, işyerleri, fabrika, sgk, tarım) çıkarılmıştır. Sonrasında faktör analizi sonucunda ifadeler 7 alt boyuta ayrışmıştır. Bu ifadelerin Kaiser-Meyer-Olkin (KMO) değeri 940, df 1035 ve Sig. .000 olarak bulunmuştur. 7 alt boyut ise örneklemin 59,608'ini aç1klamaktadır. Elde edilen faktör grupları, önceki çalışma ile çok büyük benzerlikler taşıdığı için ayrışan faktör gruplarına aynı isimler verilmiştir. Buna göre "vatanseverlik ve milliyetçilik" olarak adlandırılan ilk faktör yapısında; şehitlik vatan, millet, ordu, bayrak, milliyetçilik, ülke, polis, devlet, asker ifadeleri yer almıştır. "Para ve ekonomi" boyutu; banka, borsa, bürokrasi, belediye, basin Imedya ve para ifadeleriyle; "demokrasi ve hukuk devleti" boyutu; hukuk, kanun, mahkeme, eğitim, kitap, anayasa ifadeleriyle; "din ve gelenek" boyutu; din, ahlak, akraba ve aile ifadeleriyle; "eğitim ve öğretim" alt boyutu; okul, üniversite ve öğretmen ifadeleriyle faktör grubu oluşturmuştur. Son olarak, önceki çalışmada "Anti Modern-Din ve Gelenek" alt boyutunda ayrışan "sinema" ve "tiyatro" ifadeleri bu çalışmada 
ayrı bir gruplaşma gösterdiği için; 7. alt boyut olarak bu ifadelere "sanat" adı verilmiştir. 20 yıl sonra bu farklı gruplaşmadan yola çıkarak üniversite gençliğinin sinema ve tiyatroya atfettiği anlamın daha aslınauygun olduğunu söyleyebiliriz. Şüphesiz bu durum ülkemizde sinema sektörünün gelişmesi, sinemanın daha yaygın ve erişilebilir hale gelmesi ile yakından ilişkilidir. Günümüzde sanatsal faaliyetlerin ve boş zaman etkinliği alternatiflerinin arttığını düşündügümüzde, entelektüel anlam atfedilerek örneğin "tiyatroya gitme" nin gençler arasında amaçlı bir tercih haline dönüştüğü söylenebilir. Çalışmanın ilerleyen kısımlarında kurumların değeri ölçeğinin bulgularını değer yönelimleri ölçeği ile ilişkilendireceğiz.

Bu çalışmada kullanılan değer yönelimleri faktör alt boyutlarının ortalama puanlarını devlet ve vakıf üniversitesi olarak karşılaştırdığımızda; ortalama değerlerin büyük oranda benzeştiği görülmüştür. Bazı değer altboyutlarının ortalaması Devlet Üniversitelilerde az farkla daha yüksektir. Bunlar bireyci yönelim, akılcı yönelim, toplumsal yönelim ve uyarcılık yönelimi alt boyutlarıdır. Diğer taraftan Vakıf Üniversiteliler ise iyilik hali ve özgeci yönelimde daha yüksek ortalama puana sahiptir. Buradaki bulgu genel yargıları tersine çevirmektedir. Seküler, maddi ya da görünürlükçü ifade edebileceğimiz uyarıcıllk bireycilik, akılcılık gibi değer yönelimleri, Vakıf Üniversitesi öğrencilerinin daha yüksek gelire sahip olduğu verisi ile birlikte düşünüldüğünde, açıkçası bahsedilen alt boyutların bu kategoride daha yüksek ortalama puanlarına sahip olacağını bekliyorduk. Fark çok az olsa da (örn. ortalama puanlar arası bireycilik yönelimindeki fark 0,0361; akılcı yönelimdeki fark 0,0964, uyarıcılık yönelimindeki fark 0,1567 ) bu bulgunun değerlendirilmesi gerekir. Açıkçası bu durumu Konya'daki vakıf üniversitesi öğrencilerinin çoğunlukla Konyalı olması ile bağlantılı buluyoruz. Konya'nın görece muhafazakâr yapısı değer yönelimlerine bu yönde yansımış olabilir. Çalışmanın örnekleminin seçildiği Devlet Üniversitesini önceki yıllarda genellikle iç Anadolu şehirlerinden öğrenciler tercih ederken, şimdi bu durumun dönüşerek çeşitlilik kazandığı bilgisini de hatırlamalıyız.

Her iki üniversitenin değer yönelimleri ölçeği ortalama puanları çok yakın düzeyde olduğu için, değer yönelimleri alt boyutları ile yapılacak analizlerde veriyi bölmeden, örneklemin tamamı üzerinden yorum yapmayı uygun bulduk. Alt boyutların korelasyon ilişkilerine bakıldı- 
ğında, 7 faktörün her biri arasında anlamlı korelasyon ilişkileri tespit edildi. Burada bireyci yönelim için en güçlü korelasyon özgecilik yöne$\operatorname{limi}\left(, 565^{* *}\right)$ ve toplumsal yönelim $\left(, 554^{* *}\right)$ faktörleri ile gerçekleşmiştir. Manevi yönelim; akılcı yönelim $\left(, 412^{* *}\right)$ ve iyilik hali(,418**) ile; akılcı yönelim; bireyci yönelim(,453**) ve özgeci yönelimle(,454 $\left.{ }^{* *}\right)$; toplumsal yönelim; özgeci yönelimle(,606**) anlamı düzeyde güçlü korelasyon ilişkisine sahiptir. Diğer taraftan iyilik hali; özgeci yönelim(,532**) ve toplumsal yönelim $\left(, 536^{* *}\right)$ ile; uyarıcılık yönelimi manevi yönelim(,398**) ile en güçlü korelasyona sahiptir. Ölçek alt boyutlarını cinsiyetle ilişkilendirdiğimizde ise; bireyci yönelim(ort.6,49, sd. ,7342, t=6,026, p=,000), akılc1 yönelim(ort. 6,23, sd. ,8445, t=2,980, $\mathrm{p}=, 003$ ), toplumsal yönelim (ort.6,51, sd.,6954, t=6,852, p=,000), iyilik hali (ort. 6,21, sd. ,9899, t=4,383, $\mathrm{p}=, 000$ ) ve özgeci yönelim (ort. 6,52, sd. ,6495 t=8,300, $\mathrm{p}=, 000$ ) kadın kattlımcıların lehine anlamlı farklılaşma göstermiştir. Dolayısıyla bu değer kategorilerine kadın üniversite öğrencileri daha fazla yönelmiştir. Uyarıcllık yönelimi ve manevi yönelim ise anlamı bir fark göstermemiştir. Ancak manevi yönelimde kadınların(ort. 5,189, sd. 1,194) uyarıcılık yöneliminde ise erkeklerin(ort. 5,208, sd. 1,216) ortalama puanı daha yüksektir. Fakülte bazında bakıldığında ise anlamlılık ilişkisinde edebiyat ve sosyal ve beşeri bilimler fakültesi öğrencileri(daha çok sosyoloji ve sosyal hizmet bölümü öğrencileri) en yüksek ortalama ile bireyci değerlere yönelmiştir $(\mathrm{f}=5,292, \quad \mathrm{p}=, 000)$. Akılc1 $(\mathrm{f}=4,790, \mathrm{p}=, 000)$, uyarıc1 $(\mathrm{f}=7,431$, $\mathrm{p}=, 000)$ ve özgeci $(\mathrm{f}=2,848, \mathrm{p}=, 009)$ değerlere, anlamlı ilişkide, en yüksek ortalama puanla iletişim fakültesi öğrencilerinin yöneldiği görülmektedir. Anne eğitim düzeyi ile üniversite öğrencilerinin değer yönelimleri arasında anlamlı bir farklılaşma gözlemlenmemiştir. Baba eğitim duru$\mathrm{mu}$ ise, üniversite öğrencilerinin uyarıcılık değer yöneliminde $(\mathrm{f}=2,929$, $p=, 008)$ etkili olmuştur. Bu veriye göre uyarıcılık değer yönelimi daha yüksek düzeyde olanlar; babası okuma yazma düzeyinde eğitime sahip üniversite öğrencileridir.

\section{“Üniversiteyi Kazanmak için Ne Kadar Çalıştık, Kimlerle Görüş̧ük.."}

Ülkemizde neredeyse fenomene dönüşen üniversite sınavına hazırlanma süreci ailelerin de işin içinde olduğu; çocukları ders çalışırken onların başında nöbet tuttuğu, dershaneye "düzenli gidiliyor mu" diye neredey- 
se ajana dönüştüğü, "çocuğum etkilenmesin" diye misafir kabul etmediği, (gidiş̧in gelişi olur diye) misafirliğe daha az gittiği, tatilleri ertelediği, evde bilgisayar, telefon, teknolojiye kota koyduğu, yemeyip yedirdiği, giymeyip giydirdiği, karşılığında da umudun mümkünse "iyi bir üniversitede iyi bir bölüm kazanma" idealine bağlandığı bir süreçtir. Açıçası bu ifadeleri dayandırabileceğimiz analitik veriler içeren bir çalışmaya henüz rastlamamış olsak da, sürecin hem öğrenciler hem de ebeveynler için oldukça zorlu olduğunu destekleyebilecek güçlü gözlem verilerimiz var. Sosyolojik olarak toplumun her kesiminin eşit ilgi gösterdiğini veya imkan sunduğunu söyleyebilmek mümkün değil ise de bu, daha çok orta sınıfın maddi manevi üzerinde durduğu bir durummuş gibi görünüyor. Bizim bu çalışmada, bahsettiğimiz konu ile ilgimiz, "peki bu durum değer yönelimlerini nasıl etkiliyor?" sorusu çerçevesindeydi. Üniversite öğrencilerine, (hatırlayacaklarını varsayarak) ancak geçmişe dönük birkaç soru sorma yoluyla bu konuya veri sağlamaya çalıştık. Bu çerçevede, üniversite öğrencilerinin sınava hazırlanma sürecinde ortalama ders çalışma saatleri ile değer yönelimleri alt boyutları arasındaki ilişki değerlendirildiğinde; düşük de olsa pozitif yönlü anlamlı korelasyon tespit ettik. Buna göre günlük ders çalışma saatleri arttıkça bireysel değerlere yönelme düzeyi de artmış $\left(, 081^{*}\right)$ fakat aynı ilişkide; sosyal adalet, sosyal düzen, sorumluluk ve sağlıklı olmak ifadelerinin gruplaştığ1 toplumsal değerler yönelimi ile $\left(0,065^{*}\right)$ zayıf düzeyde de olsa olumlu yönde korelasyon bulunmuştur. Herhangi bir bireyin ya da gencin, üniversite sınavına hazırlık aşamasında da olsa, genel ve toplumsala dönük olumlamayı işaret eden değerleri sınava çalışma saatleri artsa dahi önemli görmesi muhtemeldir. Ancak bu uzayan saatler, bireyci değerlere yönelimi arttırıyor ise; değer aktarımında merkezi konumdaki sosyal ilişkilerden kopuşun ya da uzak kalışın bu süreçle bağlantısını da göz önünde bulundurmalıyız.

Sınava hazırlanırken günlük ortalama çalışma saati verisini güçlendirebilmek amacıyla, aynı değişkeni sosyal ilişki düzeyleri ile değerlendirdiğimizde; bu süreçte \%70 ten fazlası günde 1 saat-4 saat arası zaman dilimini aile üyeleri ile paylaşımda bulunarak geçirdiğini ifade ederken örneklemin \%52'sinden fazlası yakın akrabaları ile ayda en az bir olmak üzere, çoğunlukla(\%22) haftada bir iki gün görüşmüştür. Diğer akrabalarla durum biraz daha farklıdır; üniversite sınavına hazırlanırken öğ- 
rencilerin \%43,8'i diğer akrabalarla neredeyse hiç görüşmemiştir. $\% 19,7^{\prime}$ si ise birkaç ayda bir görüştüğünü ifade etmiştir. Arkadaşlarla ise görüşme sıklığ1 daha yoğun düzeydedir; en az haftada bir görüşenler örneklemin \%80'den fazlasıdır. Oranlar içinde çoğunluk(\%29) günde ortalama 3-4 saat arkadaşına vakit ayırabilmiştir. Bu oranları bölüm bazında değerlendirdiğimizde, örneğin hukuk ve tıp fakültesi gibi yüksek puanlarla kazanılan bölümlere yerleşen öğrencilerin sosyal ilişki düzeyleri çok da düşük düzeyde görünmemektedir.

Sınava hazırlanma süreci ve değerler arasındaki ilişki konusunda güçlü açıklama yapabilmek için şüphesiz daha çok veriye ihtiyacımız var. Bu çerçevede, en çok dikkati çeken yüksek oran olarak diğer akrabalarla görüşme (ya da nadir görüşme ve neredeyse hiç görüşmeme) düzeyleri ile değer yönelimleri arasındaki ilişkiye bakmak amacı ile yapılan ANOVA Testi sonuçları ise çarpıcı bir sonuç ortaya koydu. Buna göre kadın katılımcıların özgeci, iyilik hali ve toplumsal değer yönelimi alt boyutları anlamlı bir farklılaşma gösterirken, özellikle diğer akrabaları ile hergün en az 1-2 saat görüşenlerin kadınlar olduğu ortaya çıtı. Erkeklerde ise aynı değişken ile manevi yönelim arasında anlamlı bir fark vardı; erkeklerde de yine diğer akrabaları ile günde 1-2 saat görüssenler manevi değer yönelimi daha yüksek olanlardı. Bu sonuç bizlere aslında şunu gösteriyor; akrabalarla görüşme, onlarla kurulan ilişkiler ve sosyal alışveriş; uyarıcı, bireyci ya da akılcı değer yönelimleri yerine, toplumsal, özgeci, manevi ve iyilik hali türünde değerleri pekiştirici rol oynamaktadır. Diğer taraftan akrabalarla görüşme erkeklerde manevi değerler üzerinden, kadınlarda ise daha sosyal ilişkileri ya da kurumları ifade eden daha toplulukçu değerler üzerinden algılanıyor görünmektedir.

Aynı süreçte sosyal etkinliklere katılma düzeyine baktı̆̆ımızda ise örneklemin \%16,6'sı neredeyse hiç katılmadığını belirtirken \%28'i nadiren katılmıştır. Ara sıra katılanlar \%36 oranındadır. Bunlar arasında kadın katılımcilar daha yüksek oranda neredeyse hiç görüşmeyenler ya da ayda yılda bir görüşenler olmuştur. Üniversite gençliği, sınava hazırlanırken özellikle arkadaş bazında sosyal ilişkilerden çok da izole olmamışlarsa da akrabalarla görüşme kapasitelerinin kısıtlı olduğu ifade edilmelidir. Diğer taraftan hazırlık sürecinde sosyal medya kullanım sıklıkları da \%60,8 düzeyinde günde en az bir saatten az olmak kaydıyla 
bunların içerisinde 1-3 saat kullananlar ise örneklemin \%38,6'sıdır. Neredeyse hiç kullanmamayı başarabilenler $\% 18,4$ düzeyindedir.

\section{Önceki ve Şimdiki Çalışma Kıyasında Daha Net Bir Bulguya Doğru: 20 Yil Sonra Neredeyiz..}

Son olarak bu çalışmada gerçekleştirilen alan araştırması verilerinin20 yıl önceki çalışma ile en kıyaslanabilir değişkenleri üzerinde duracağız. Önceki çalışmada Schwartz'ın değer yönelimleri ifadelerinden oluşan 57 maddelik ölçek, işlemeyen maddelerin çıkarılması sonrasında faktör analizi doğrultusunda 8 alt boyuta ayrışmış, daha sonra 2. seviye faktör analizi yapılarak 3 boyut bulunmuştu(Topçuoğlu, 1999, s.59). Bu faktörler ise, maddi yaşam ve zevk, dindarlik ve gelenekçilik ile uyum faktörlerinin birleşmesi ile oluşturulan "maddecilik yönelimi"; sosyal güç ve itibar ile maceracılık faktörlerinin gruplaşmasıyla oluşan "bireycilik yönelimi" ve son olarak da bilgelik, özgecilik ve çevrecilik ile araştırıcilık boyutlarının gruplaştığı "evrensellik yönelimi” faktörüdür. Aynı şekilde kurumların değerleri için de 2. seviye faktör analizi yapılmış, öncesinde 6 farklı alt boyuta ayrışan kurum ifadeleri, bu işlem sonrasında 3 alt gruba ayrışarak maddecilik(para ve ekonomi, demokrasi ve hukuk devleti), üretkenlik (üretim ve çalışma, eğitim ve öğretim) ile maneviyatçılık (anti modern, din ve gelenek, vatanseverlik ve milliyetçilik) olarak yeniden adlandırılmıştı.

Tablo 5. Değer yönelimleri ile kamusal yönelimler arasındaki korelasyonlar(1999)

\begin{tabular}{llll}
\hline & Maddecilik & Maneviyatçllık & Üretkenlik \\
\hline Maddecilik yönelimi &, $24^{* * *}$ &,$- 21^{* * *}$ &, $23^{* * *}$ \\
Bireycilik yönelimi &, $35^{* * *}$ &, 080 &, $26^{* * *}$ \\
Evrensellik yönelimi &, 17 &, 01 &, 16 \\
\hline
\end{tabular}

Tablo 5'e göre maddecilik yönelimi ile tüm kurum değerleri alt boyutları ile anlamlı bir ilişki bulunmuştur. 20 yıl önceki verilere göre bu anlaml1lık ilişkisinde maneviyatçılık negatif yönlüdür. Bireycilik değer yönelimi ile maddecilik ve üretkenlik kurum değeri arasında ise yine anlam ilişkide pozitif yönlü korelasyon bulunmuştur.Bu faktörlerin kısmi korelasyon ilişkisinde ise bireycilik değer yönelimi bütün kurumsal yönelimlerle ilişkide gözükürken evrensellik yönelimi hiçbir alt boyutla anlamlı ilişkide 
çıkmamıştır(bkz. Topçuoğlu, 1999, s. 92-93). Aynı analizde maddecilik değer yönelimi ise yine kurum değerlerini tüm boyutlarıyla anlamlı ilişki göstermiş ancak maneviyatçılık ile bu ilişki tekrar olumsuz yönlü bulunmuştur. Burada olumlular doğrusal bir ilişki kurarken maddecilik yönelimi ve maneviyatçılı $k$ arasında biri artarken diğeri azalan, dolayısıyla da doğrusal olmayan bir anlamlılık ilişkisi vardır.

Tablo 6'da ise bu çalışmada elde edilen değer yönelimleri ölçek alt boyutları ve kurumların değeri ölçeği alt boyutlarının her ikisinin de faktör analizi ile 3'yordanması ile elde edilmiştir. Daha önce de belirttiğimiz gibi değer yönelimleri ölçek ifadeleri önceki çalışmadan farklı bir faktör ayrışımı gösterdiği için, bu çalışmada değer yönelimleri 3'e yordandığında, bir tane farklı faktör yapılaşması ortaya çıkmıştır. Buna göre eski çalışmada ,( dindarlık ve gelenekçilik, uyum, maddi yaşam ve zevk faktör grupları ile oluşan bkz. Topçuoğlu, 1999; 59) maddecilik yönelimi, bu çalışmada maddecilik ve bireysellikadı verilen alt boyutta ayrışmış, (itaatkârlık, kabullenme, dindarlık, iyiliklerin ödenmesi, gelenek ve göreneklere saygı ve manevi yaşam ifadeleri ile ayrışan) yeni gruplaşmaya manevi yönelim ismi verilmiştir. Kaiser-Meyer-Olkin KMO değeri 902 ile 3 faktör örneklemin \%43,33'ünü açıklamaktadır. Kurumların değeri ölçeği, önceki çalışma ile neredeyse birebir örtüşen ayrışma ile maddecilik, maneviyatçılı, ve üretkenlik alt boyutları ile Kaiser-Meyer-Olkin KMO değeri ,927; açıkladığı varyans değeri ise, $\% 46,8$ 'dir.

Tablo 6.Değer yönelimleri ile kamusal yönelimler arasındaki korelasyonlar(2018)

\begin{tabular}{llll}
\hline & Maddecilik & Maneviyatçllık & Üretkenlik \\
\hline Manevi yönelim &, $284^{* *}$ &, $336^{* *}$ &, $131^{* *}$ \\
Bireycilik ve maddecilik yönelimi &, $303^{* *}$ &, $165^{* *}$ &, $278^{* *}$ \\
Evrensellik yönelimi &, $238^{* *}$ &, $313^{* *}$ &, $287^{* *}$ \\
\hline
\end{tabular}

Tablo 6'da görüldüğü üzere bütün faktör boyutları arasında pozitif yönlü anlamlı ilişkiler mevcuttur. Burada kurumların değeri ile değer yönelimleri arasındaki ilişkiler özellikle manevi yönelim ve üretkenlik arasında çok düşük olsa da anlamı pozitif yönlü bir ilişki bulunmuştur buna göre manevi yönelim arttıkça üretkenliğe ilişkin kurumlara verilen değer de artmaktadır. Bireycilik yönelimi de üretkenliği düşük korelasyon gücü ile de olsa artırıyor görünmektedir. Ancak buradaki en çarpıcı 
bulgu; geçmiş çalışma ile kıyaslandığında bireycilik ve maddecilik yönelimi ile maneviyatçılık arasındaki gücü az da olsa, pozitif yönlü korelasyon ilişkisidir(,165**). Aynı olumlu anlamlı ilişki manevi değer yönelimi ile maddecilik kurum değeri alt boyutu arasında da bulunmakta$\operatorname{dır}\left(, 284^{* *}\right)$. Ayrıca bu çalışmanın kendi değer yönelimi 3 faktörlü yapısı korelasyon ilişkilerine bakıldığında benzer ilişkiyi kuvvetle doğrulayan bir bulgu olarak, bireyci yönelim ve manevi yönelim arasında da $493^{* *}$ değeri ile daha güçlü anlamlı bir ilişki bulunmuştur. Dolayısıyla üniversite gençliği; 20 yıl önce maddi ve manevi değerler arasında karşıt yönlü bir algılamaya sahipken, maneviyatçılık arttığında maddi değerlere yönelim azalıyorken(veya tam tersi iken) günümüzde ise madde ve mananın, dolayısıyla; akıllı olma, başarılı olma, kendi yönünü belirleyebilme gelenek ve göreneklere saygı, dindarlık, hırs, güzelliklerle dolu bir dünya ve imaj değerleri birbirini olumlar görünmektedir.

\section{Sonuç Yerine Değişimi Nasıl Anlamlandırmalıyız?}

Bu çalışma ile değerlerin yıllar içerisindeki dönüşümü konusundaki gözlemlerimizi kısmen de olsa bazı analitik bulgular çerçevesinde anlamaya çalıştık. Şüphesiz burada manevi yaşama ilişkin değerlerin maddi değerlerle benzer biçimde algılanmaya başladığı görülmektedir. Araştırmacıların milenyum kuşağından farklı olduğunu ifade ettiği, bizim de örneklemimizin içine dahil olduğu, 1995-2012 arası doğumluların aslında çok başka bir dünyaya doğduklarını düşünen Stillman (2017), bu nesli tanıyabilmemiz konusunda genç kuşağın değişimini konu ettiği çalışmasında araştırmalara dayalı farklı bilgilere yer vermektedir. Bu çerçevede; üniversite gençliğinin de içinde olduğu bu kuşak, bir kere fiziksel yönü olan her şeyin dijital bir karşılığı olduğu bir dünyada doğan ilk kuşaktır. Sanal dünya aslında onların gerçekliğinin bir parçasıdır. Bu nesil aynı zamanda kişiselleştirme yeteneğine sahip insanlar olarak, davranış ve isteklerini karşısındakilerinin anlamasını bekleyen bir nesil; oldukça gerçekçiler, krizler ve terör olayları tecrübe ettiler, bu onların idealizmini etkiledi ve onları faydacı yaptı. Ciddi biçimde kaçırma korkusu yaşıyorlar; evet tüm yeni akımları ve rekabetleri yakından takip edecekler ama bu onları kaygılı ve endişeli bir ruh haline büründürüyor. Aynı anda birçok şey yapmak istiyor, bir şeyleri kaçırmaktan korkuyorlar. Onlar 
videolarla büyüdüler o yüzden biraz başına buruk ve "kendin yap"çılar. Ve her şeyin ötesinde hırslılar, ebeveynleri onlara katılımdan çok kazananlar ve kaybedenler üzerine düşünmeyi öğretti; ilerlemek için yoğun baskı hissettirildi ve sabırsız davranıldı. Değişim hızlı, ayak uydurmak zor, o yüzden hırslı ve rekabetçi olmalılar. Burada bahsedilen özellikleri ifade eden bulgular her ne kadar farklı bir coğrafyaya ait olsa da, bizdeki/ülkemizdeki gençlik için de benzer durumları gözlemleyebiliyoruz. Nitekim değer ifadeleri ortalama puanlarını değerlendirdiğimizde, kabullenme ve itaatkarlık, dindarlık, gelenek ve göreneklere saygı gibi değerlerle birlikte hırslı olmak, başarılı olmak, kendine saygı, kontrol gücü, refah içinde bir dünya, olaylar ve insanlar üzerinde etkili olmak "değer" kazanmış görünmektedir. Eski ile kıyaslandığında; manevi değerler de maddi değerler de artma eğilimindedir. Bu durumda, gençliğin dindarlık, hırslı olmak, etkili olmak, itaatkârlık, kontrol gücü gibi değerlere atfettikleri anlamı nitel olarak çözümlemek önemlidir. Dolayısıyla bu değişimi anlayabilmek ve yorumları analitik bulgularla geliştirerek destekleyebilmek için çok daha fazla veriye ihtiyacımız var. Son söz olarak bu çalışmanın elde ettiği bulgular çerçevesinde; öncelikle bu çalışmanın yazarlarına, sonrasında da değerler ve gençlik konusunu araştıranlara/araştırmak isteyenlere bazı önerilerimiz var. Bu çalışmanın ilk önerisi, çok somut bulguladığımız bireysellik, maddecilik gibi değer ve kurum değeri yönelimleri ile olumlu anlamlı ilişki bulduğumuz ve dinsel değer ifadelerini içererek ayrışan manevi değerler ilişkisini daha derinlemesine anlayabilmek için dindarlığın alt boyutları ile karşılaştıracak çalışmalar yapılması yönünde. Diğer önerimiz ise aileleri anlamak; ailenin eski değerini yitirdiğine dair söylemler genelleşirken bu çalışmada en yüksek ortalama puan alan değer ifadesi "ailenin güvenliği"(ort. 6,786) oldu. Gençler için aile çok önemli ve önemli ölçüde ebeveynlerin davranış ve tutumları, çocukluktan itibaren onların değer dünyaları üzerinde etkili. Peki, ailelerin değer yönelimleri nasıl ayrışıyor? Gençlerle benzeşiyor mu? Kuşakla ilişkilendirilebilir tarafları ne? Gençlerdeki bu değişim, aynı zamanda ebeveynlerin yetiştirme tarzındaki değişimle örtüşüyor mu? Gençlik ve değerler konusu, bu soruları cevaplayacak analitik bulgularla şüphesiz farklı çerçeveleri gün yüzüne çıkaracak. 


\title{
EXTENDED ABSTRACT
}

\section{The Values Of University Youth: What Has Changed After Years? \\ *}

\author{
Abdullah Topçuoğlu - Gamze Aksan
}

Selçuk University

This study is basically about the values of university youth. Along with the rapid sociological changes, it is obvious that the youth is one of the fore-coming social layers which has been affected by the developments being lived with in all components of the society especially following the years of the 2000's. Therefore, the question "What direction do the affairs of the youth evolve?" is a big concern both among the individual sand the society groups; especially this question is an important issue that keep busy some leading social actors of the society such as politicians, educational institutions, religious organization sand the family members. At this point, there is an obvious need for critical thinking and scientific studies which will support basic perceptions and observations. This research study is inspired by the study named "The Values of University Youth" which was implemented by Topçuoğlu in 1999. After 20 years, in this study, which aims to understand today's university youth's attitude level towards values in relation with different variables, the assessment instruments were taken from the cited research study so as to ensure reliable comparison and reach correct conclusion. The data, which is derived from 927 participants who are studying at public and private universities, is used to make deduction. The 7 factor groups that have been reached at the end of the analysis and the other variables were evaluated and compared to the findings that was gathered in former study. One of the most striking findings which helped to see the changes after 20 years is that by using Schwart's Human Value Questionnaire(1992) the positive correlative relation between distinctive individualist group sand spiritual groups is identified. 
According to the correlation analysis, there are significant positive relationships between all factor dimensions. Although the relations between the value of institutions and value orientations are very low, especially between spiritual orientation and productivity, a meaningful positive relationship has been found. As the spiritual orientation increases, the value given to institutions related to productivity also increases. Individualism orientation also seems to increase productivity, albeit with low correlation power. However, the most striking finding here; it is a positive correlation relationship between individualism and materialism orientation and spirituality, when compared to the previous study. The same positive meaningful relationship exists between the spiritual value orientation and the sub-dimension of the substance value of the institution of materialism. In addition, when the correlation relationships of the 3-factor structure of this study were examined; As a finding that strongly confirms the similar relationship, a stronger meaningful relationship was found between individualistic orientation and spiritual orientation with the value of $493^{* *}$. The university youth opened; 20 years ago, while there was an opposite perception of material and spiritual diversity, when spiritualism increased, orientation towards material values was not diminishing (or vice versa); being successful, being able to determine their own direction and approval, a world full of piety, ambition, beauties and image differences seem to appear.

It is seen that the values related to spiritual life are perceived in a similar way to the material values. Stillman (2017), who believes that the researchers are different from the millennium generation, and that we are included in our sample and that the births between 1995 and 2012 were actually born to a very different world, gives different information based on the researches about the change of the younger generation to recognize this generation. In this context; This generation, including university youth, is the first generation to be born in a world where everything with a physical aspect is a digital counterpart. The virtual world is actually a part of their reality. This generation is also a generation of people who are capable of personalization, waiting for others to understand their behavior and desires; they have experienced quite realistic crises and terrorist incidents, which affected their idealism and made them utilitarian. They have a serious fear of kidnapping; yes they will follow all the 
new trends and rivalries closely, but this makes them a worried and anxious spirit. They want to do many things at the same time, they are afraid of missing something. They grew up with videos, so they're bitter and do it yourself. And above all, ambitious, their parents taught them to think about winners and losers rather than participation; intense pressure and impatience to move forward. Change is fast, hard to keep up with, so they must be ambitious and competitive. Although the findings that refer to these characteristics belong to a different geography, we can observe similar situations for the youth in our country. As a matter of fact, when we evaluate the mean scores of expressions of value, being ambitious with values such as acceptance and obedience, piety, traditions and customs, being successful, self-esteem, control power, a world in prosperity, events and people seem to have gained "value". Compared with the old; moral values and material values tend to increase. In this case, it is important to analyze qualitatively the meaning attributed to values such as religiosity, ambitiousness, influence, obedience and control. Therefore, we need much more data to understand this change and to support interpretations with analytical findings. As a final word, within the framework of the findings of this study; firstly, we have some suggestions for the authors of this study, and then for those who want to explore values and youth. The first suggestion of this study is that we find positive and meaningful relationships with individuality and material value orientations, which we find very concrete, and to compare the sub-dimensions of religiosity with a deeper understanding of the relationship between religious values and religious values. Our other suggestion is to understand families; While the rhetoric about the loss of the old value of the family became general, the value of the highest average score was the safety of the family. For teens, the family is very important and significantly influences parents' behavior and attitudes, their value worlds from childhood. So how do families' value orientations differ? Does he resemble young people? What are the attributes associated with the belt? Does this change in youth coincide with the change in the way parents are raised? The issue of youth and values will undoubtedly reveal different frameworks with analytical findings to answer these questions. 


\section{Kaynakça / References}

Abercrombie, N., Hill, S. ve Turner, B. S. (1984). Dictionary of sociology. Harmondsworth, UK: Penguin.

Aksan, G. (2016), Max Weber ve değerler sosyolojisi: Bir metodolojik ikilemin düşündürdükleri, Selçuk Üniversitesi Edebiyat Fakültesi Dergisi, 35, 427-446.

Akyüz, İ. (2014). Türkiye'de gençlik, din ve değerler konusunda yapılan ampirik araştırmaların yöntem ve içerik analizi, Sakarya Üniversitesi İlahiyat Fakültesi Dergisi, 17(30), 1-20.

Allport, C. W., Vernon, P. E. ve Lindzey, G. (1960). A study of values. Boston: HoughtonMifflin.

Birekul, M. ve Alkın, R. C. (2015). Sosyolojinin doğuşunda değerler problemi, kurucu sosyologlardan değerler üzerine felsefi bir tartışma. (H. H. Bircan ve B. Dilmaç. ed. ) Değerler Bilançosu, içinde (77-97). Konya: Çizgi Kitabevi.

Coşkun, Y., ve Yıldırım, A. (2009). Üniversite öğrencilerinin değer düzeylerinin bazı değişkenler açısından incelenmesi. Yüzüncü Yıl Üniversitesi Ĕ̆itim Fakültesi Dergisi. 1 (6), 311-328.

Çalışkan, H. ve Karademir, Ç. (2014). Değer Yönelimleri Ölçeğinin Türkçe'ye Uyarlanması. Journal of ValuesEducation, 12 (28), 47-68

Dilmaç, B., Deniz, M. ve Deniz, M. E. (2009). Üniversite öğrencilerinin öz-anlayışları ile değer tercihlerinin incelenmesi. Değerler Ĕ̆itimi Dergisi, 7(18), 9-24.

Ergüder, Ü., Esmer, Y. ve Kalaycioğlu, E. (1991). Türk toplumunun değerleri. İstanbul: TÜSİAD.

Ersoy, E. (2018). Sosyolojide değerler ve değer araştırmaları. Uluslararası Sosyal Araştırmalar Dergisi / The Journal of International SocialResearch, 11(56), 356-366.

Giddens, A. (1998). Modernliğin sonuçları, İstanbul: Ayrıntı Yayınları.

Gökçe, O. (1994). Türk gençliğinin sosyal ve ahlaki değerleri. Ata Dergisi, Konya: S.Ü. Yayınları.

Güngör, E. (1993). Değerler psikolojisi. Amsterdam: Hollanda Türk Akademisyenler Birliği Vakfı Yayınları. 
Helve, H. (2015). Re-thinking youth and citizenship:Value groups and citizen types of young Finns. Italian Journal of Sociology of Education, 7(1), 32-66.

Inglehart, R. F. (1976). Changing values and attitude stoward military service among the American public. In (N. Goldman, ve D. Segal ed.) The Social Psychology of Military Service (p. 255-280), Beverly Hils: Sage.

Inglehart, R. F. (1977). The silent revolution: Changing values and political styles among Western publics. Princeton: Princeton UniversityPress.

Inglehart, R. F. (1982). Changing values in Japan and the West. Comparative Political Studies, 14 (4), 445-480.

Inglehart, R. F. (1997). Modernization and postmodernization: Cultural, economic and political change in 43 societies. Princeton: Princeton University Pres.

James, L. S.(1983). The sociology of values. Ann. Rev. Sociol, 9, 27-49

Kağıtçıbaşı, Ç. (1972). Gençlerin tutumları; kültürlerarası bir karşılaştırma. Ankara: ODTÜ Fen Edebiyat Fakültesi Yayınları

Karslı, B. (2016). Robert M. Pirsig'in romanlarında işlevsel değer eleştirisi, Atatürk Üniversitesi Sosyal Bilimler Enstitüsü Dergisi,20(4), 16011621.

Kıran, Ö. (2016). Üniversite öğrencilerinin değer yönelimleri:OMÜ örneği. Journal of International SocialResearch, 9(43), 1266-1266. https://doi.org/10.17719/jisr.20164317695

Kluckhohn, C. (1951). Values and value-orientations in the theory of action: An exploration in definition and classification. In (T. Parsons ve E. Shils Eds.), Toward a general theory of action (p. 388-433). Cambridge, MA:HarvardUniversityPress.

Kusdil, M. E., ve Kagitçibasi, Ç. (2000). Türk ögretmenlerin değer yönelimleri ve Schwartz değer kuramı. Türk Psikoloji Dergisi, 15, 59 80.

Marshall, G. (1999). Sosyoloji sözlüğ̈̈̈. (O. Akınhay-D. Kömürcü çev.) Ankara: Bilim ve Sanat Yay.

Mehmedoğlu, A. U. (2006). İlahiyat Fakültesi öğrencilerinin değer yönelimleri ve dindarlık-değer ilişkisi: Marmara Üniversitesi İlahiyat Fakültesi örneği. Marmara Üniversitesi İlahiyat Fakültesi Dergisi, 30, 133-167. 
Osgood, C.E., Suci, G.J. ve Tannenbaum, P.H. (1957). Exploration in Semantic Space. Journal of Social Issues, 27, 5-64.

Öngen, B. ve Serpil, A. (2013). Üniversite öğrencilerinin toplumsal cinsiyet rollerine ilişkin tutumları ve yaşam değerleri ilişkisi. Sosyoloji Konferansları, 48, 1-18.

Özcan, Z. ve Erol, H. (2017). Üniversite öğrencilerinin değer yönelimleri ve dindarlık-değer ilişkisi:Karabük örneği. Journal of History Culture and Art Research, 6(4),913-947. doi:http://dx.doi.org/10.7596/taksad.v6i4.1091

Özensel, Ertan (2003). Sosyolojik bir olgu olarak değer, Değerler Eğitimi Dergisi. 1(3), 217-239.

Pickering, M. (2009). Aguste Comte: An intellectual biography volume II. USA: Cambridge UniversityPress.

Ritzer, G. (2011). Sociological theory (8th Ed.). Boston: McGraw-Hill.

Rokeach, M. (1968). Beliefs, attitudes, andvalues: A theory of organization and change. San Francisco: Jossey-Bass.

Rokeach, M. (1973). The nature of human values. New York: TheFreePress.

Rokeach, M. (1979). Some unresolved issues in theories of beliefs, attitudes and values. In (H. E. Howe, Jr., ve M. M. Page Eds.), Nebraska Symposium on Motivation (Vol. 27). Lincoln: University of Nebraska Press.

Schwartz, S. (1992). Universals in the content and structure of values: Theoretical advances and empirical tests in 20 countries. In(M.P. Zanna, Ed.); Advances in experimental social psychology, (vol 25, p. 1-65), San Diego: AcademicPress.

Schwartz, S. H. ve Bilsky, W. (1990). Toward a theory of theuniversalcontent and structure of values: Extensions and cross cultural replications. Journal of Personality and Social Psychology, 58 (5),878891.

Schwartz, S., ve Bilsky, W. (1987). Towards a universal psychological structure of human values. Journal of Personalityand Social Psycho$\log y, 53$ (3), 550-562.

Simmel, G. (2014). Paranın felsefesi, (Y. Alogan ve Ö. D. Aydın çev.). İstanbul: İthaki Yayınları.

Stillman, D. Ve Stillman, J. (2017). İşte Z kuşă̆ı. (D. P. Kayıhan ve F. Erduran Çev.), İKÜ Yayınevi: İstanbul. 
Theodorson, G.T. ve Achilles, G. (1969). A modern dictionary of sociology. New York: A BarnesandNoble

Thomas, W. I., ve F. Znaniecki. (1984) The Polish peasant in Europe and America. Urbana: University of Illinois Press.

Thomson, R. Ve Holland, J. (2004) Youth values and transitions to adulthood: An empirical investigation. London:London South Bank University.

Topçuoğlu, A. (1999). Üniversite gençliğinin değerleri. Ankara: Vadi Yayınlar1.

Ülken, H. Z. (1965). Bilgi ve değer. Ankara: Kürsü Yayınları.

Ülken, H. Z. (1965). Değerler, kültür ve sanat. Değerler, kültür ve san'at; İstanbul: Kâğıt ve Basım İşleri Mat.

VonScheve, C. (2015). Societal origins of values and evaluative feelings. In (T. Brosch, ve D. Sander, eds) The Handbook of Value: Perspectives from Economics, Neuroscience, Philosophy, Psychology and Sociology, (175-195) .New York: Oxford University Press,

Weber, M. (1999). Protestan ahlakı ve kapitalizmin ruhu. (Z. Gürata çev). Ankara: Ayraç Yay.

Weber, M. (2012). Ekonomi ve toplum. (L. Boyacı çev.). İstanbul: Yarın Yay. Wiley, N.(1986). Early American sociology and the Polish peasant author(s). Sociological Theory, 4(1) 20-40.

\section{Kaynakça Bilgisi / Citation Information}

Topçuoğlu, A. ve Aksan G. (2019). Üniversite gençliğinin değerleri: 20 yıl sonra ne değişti?. OPUS-Uluslararası Toplum Araştırmaları Dergisi, 11(18), 2241-2274. DOI: 10.26466/opus.571209 